\title{
Thrombus Degradation by Fibrinolytic Enzyme of Stenotrophomonas sp. Originated from Indonesian Soybean-Based Fermented Food on Wistar Rats
}

\author{
Florensia Nailufar, ${ }^{1,2}$ Raymond R. Tjandrawinata, ${ }^{1,2}$ and Maggy T. Suhartono ${ }^{2,3}$ \\ ${ }^{1}$ Dexa Laboratories of Biomolecular Sciences, Jalan Industri Selatan V Blok PP/7, Jababeka II, Cikarang 17550, Indonesia \\ ${ }^{2}$ Faculty of Biotechnology, Atmajaya University, Jalan Jenderal Sudirman 51, Jakarta Selatan 12930, Indonesia \\ ${ }^{3}$ Department of Food Science and Technology, Faculty of Agricultural Engineering and Technology, \\ Bogor Agricultural University, Bogor 16002, Indonesia
}

Correspondence should be addressed to Maggy T. Suhartono; mthenawidjaja@yahoo.com

Received 11 March 2016; Revised 11 July 2016; Accepted 26 July 2016

Academic Editor: Paola Patrignani

\begin{abstract}
Copyright (c) 2016 Florensia Nailufar et al. This is an open access article distributed under the Creative Commons Attribution License, which permits unrestricted use, distribution, and reproduction in any medium, provided the original work is properly cited.

Objective. To evaluate thrombus degrading effect of a fibrinolytic enzyme from food origin Stenotrophomonas sp. of Indonesia. Methods. Prior to animal study, the enzyme safety was tested using cell culture. The effect on expression of tissue plasminogen activator was also analysed in the cell culture. For in vivo studies, 25 Wistar rats were used: normal control, negative control, treatment groups with crude and semipurified enzyme given orally at $25 \mathrm{mg} / \mathrm{kg}$, and positive control group which received Lumbrokinase at $25 \mathrm{mg} / \mathrm{kg}$. Blood clot in the tail was induced by kappa carrageenan injection at $1 \mathrm{mg} / \mathrm{kg}$ BW. Results. Experiment with cell culture confirmed the enzyme safety at the concentration used and increased expression of tPA. Decreasing of thrombus was observed in the positive group down to $70.35 \pm 23.11 \%$ of the negative control animals $(100 \%)$. The thrombus observed in the crude enzyme treatment was down to $56.99 \pm 15.95 \%$ and $71.5 \pm 15.7 \%$ for semipurified enzyme. Scanning electron microscopy showed clearly that bood clots were found in the animals injected with kappa carrageenan; however, in the treatment and positive groups, the clot was much reduced. Conclusions. Oral treatment of enzyme from Stenotrophomonas sp. of Indonesian fermented food was capable of degrading thrombus induced in Wistar rats.
\end{abstract}

\section{Introduction}

Cardiovascular diseases are reported as the leading cause of 17.5 million people deaths [1]. By 2030, more than 23 million people estimated will die each year due to cardiovascular disease, with acute myocardium infarction because of thrombosis of blood vessels [2]. The present drug, human tissue plasminogen activator ( $\mathrm{t}-\mathrm{PA}$ ), is a major activator of the extrinsic fibrinolytic system [3] and a member of serine protease family, which is involved in fibrinolysis [4]. Thrombolytic drug which dissolve fibrin in the blood clots are used not only for myocardial infarction but also for thromboembolic strokes, deep vein thrombosis, and pulmonary embolism to clear the blockage of blood vessel $[5,6]$. Thrombolytic therapy with t-PA at present is limited by the relatively high incidence of reocclusion and resistance to reperfusion, despite therapeutic heparinization $[7,8]$.

Tissue plasminogen activators, streptokinase and urokinase, activate plasminogen into active plasmin, which further degrade fibrin in the blood clots. Another potent thrombolytic agent lumbrokinase of the earth worm Lumbricus and lumbrokinase-like proteins degrade fibrin directly [8-10].

Streptokinase and urokinase are also considered effective drugs for thrombolytic therapy. However, beside being expensive, the side effects of the drugs such as occurrence of allergic reactions due to streptokinase administration have been reported. Attempts to finding new and safe drugs of more natural origin are thus being actively pursued.

Microorganisms have been recognized as source of thrombolytic agent, such as streptokinase from Streptococcus 
hemolyticus and staphylokinase from Staphylococcus aureus [2]. More attention is given to microbial fibrinolytic enzymes of food origin, in particular, the traditional fermented foods, which have been consumed safely for decades. Later discovery reported potent thrombolytic agent nattokinase (NK) from Bacillus natto isolated from Japanese fermented soybean food [2, 11]. In addition, Bacillus amyloliquefaciens DC-4 and Bacillus subtilis LD-8547 isolated from Chinese soybeanfermented food called Douchi were also found to produce thrombolytic enzymes [12, 13].

Screening and isolation of fibrinolytic bacteria from Oncom, an Indonesian soybean-based fermented food, revealed several bacteria, and among these bacteria we found Stenotrophomonas sp. This finding is unique, because most of fibrinolytic microorganism of food origin reported belongs to Bacillus sp. Safety of the bacterial enzyme from the Indonesian fermented Oncom was tested using cell culture and experimental rats, while the effect of Stenotrophomonas enzyme on degrading thrombus was observed using the experimental rats.

\section{Materials and Methods}

Three bacterial isolates from Oncom were obtained from Bogor Agricultural University, Indonesia. Kappa carrageenan and fetal calf serum (FCS) were purchased from Sigma-Aldrich, human cervix adenocarcinoma cell line (HeLa S3) and fibroblast Mus musculus cell line (3T3-SA) were purchased from the American Type Culture Collection (Rockville, MD, USA), and Dulbecco's Modified Eagle's Medium/F12 basal medium (Gibco, Carlsbad, CA, USA) and penicillin-streptomycin (Gibco) were obtained from their local representatives. Platelet count, erythrocyte, white blood cell, platelet distribution width, and mean corpuscular volume were determined by semiautomated Hematology Analyzer MEK-6450K (Nihon Kohden, Japan). Cell pack diluents (Nihon Kohden, Japan), autofine coater JEOL JFC 1600, and scanning electron microscopy JEOL JSM-6510 were provided by Dexa Laboratories of Biomolecular Sciences, Dexa Medica.

2.1. Production of Enzyme. The bacterial isolates were grown in casein medium, consisting of $0.5 \%(\mathrm{w} / \mathrm{v})$ casein, $0.5 \%$ (w/v) glucose, $0.6 \%(\mathrm{w} / \mathrm{v}) \mathrm{Na}_{2} \mathrm{HPO}_{4} 2 \mathrm{H}_{2} \mathrm{O}, 0.2 \%$ (w/v) yeast extract, $0.1 \%(\mathrm{w} / \mathrm{v}) \mathrm{KCl}$, and $0.01 \%(\mathrm{w} / \mathrm{v}) \mathrm{MgSO}_{4} 7 \mathrm{H}_{2} \mathrm{O} ; \mathrm{pH}$ of the media was adjusted to 8.5. Incubation was performed overnight at $37^{\circ} \mathrm{C}$ and $120 \mathrm{rpm}$. Absorbance was measured at $600 \mathrm{~nm}$ to follow the bacterial growth. Extracellular enzyme was harvested following centrifugation at $8930 \mathrm{~g}$ for 30 minutes. The pellet was removed, and the supernatant (crude enzyme) was kept at $-20^{\circ} \mathrm{C}$ until use. Ammonium sulphate $(65 \% \mathrm{w} / \mathrm{v})$ was added into the crude enzyme and kept at $4^{\circ} \mathrm{C}$, stirred overnight, and centrifuged at $15880 \mathrm{~g}$ for 15 minutes at $4^{\circ} \mathrm{C}$. Supernatant was removed and the pellet was collected and dissolved with phosphate buffer $20 \mathrm{mM}$, $\mathrm{pH}$ 7.5. The enzyme activity was analyzed following fibrin degradation assay [14], while the protein concentration was assayed following Lowry method [15].

2.2. Cell Cultures and Treatment. HeLa S3 cells were cultured in F12 basal medium, while 3T3 SA cells were cultured in Dulbecco's Modified Eagle's Medium supplemented with $10 \%$ fetal calf serum and $1 \%$ penicillin-streptomycin. The cells were incubated at $37^{\circ} \mathrm{C}$ in $5 \% \mathrm{CO}_{2}$ atmosphere. The medium was replaced every 2-3 days until the cells reached $80 \%$ confluence. The culture was then subcultivated at a ratio of 1:4 using $1 \mathrm{~mL}$ trypsin-ethylenediaminetetraacetic acid (Gibco). Before treatment, the cells were maintained in serum-free medium. Treatment with crude and semipurified enzyme was given at various concentrations. The experiment was repeated four times for each concentration tested, and duration of treatment was 24 hours.

2.3. MTT (Microculture Tetrazolium Salt) Assay. FCS, Lglutamine, sodium bicarbonate, penicillin, and streptomycin were added to Dulbecco's Modified Eagle's/F12 basal medium. HeLa S3 and 3T3 SA cells were multiplied and subcultured in $75 \mathrm{~cm}^{2}$ culture flask (Falcon, BD) in these media, at $37^{\circ} \mathrm{C}$ under partial pressure of $5 \% \mathrm{CO}_{2}$. The multiplied HeLa S3 and 3T3 SA cells were separated by using trypsinethylenediaminetetraacetic acid and suspended in fresh media. After reaching $80 \%$ confluent state, the cell was serum-starved before treatment with crude and semipurified enzyme. The cells were incubated with various concentrations $(0,1,3,5,10,20,40,80,160,320$, and $640 \mu \mathrm{g} / \mathrm{mL})$ of enzymes from Stenotrophomonas sp., Bacillus cereus, and Bacillus licheniformis for 24 hours. At the end of incubation, $20 \mu \mathrm{L}$ of MTT was added, and incubation was continued for another 4 hours. Finally, the plate was read using a microplate reader (BIO-RAD, USA) at $590 \mathrm{~nm}$.

2.4. Reverse Transcription Polymerase Chain Reaction. HeLa S3 cells were cultured with FCS 10\% until reaching the confluent state, treated with crude and semipurified enzyme for 24 hours, and further incubated in $5 \% \mathrm{CO}_{2}$ at $37^{\circ} \mathrm{C}$. Total RNA was extracted from HeLa S3 cells using TRIzol reagent (Invitrogen, Carlsbad, CA, USA) according to the manufacturer's recommendation. The RNA concentration was quantified using a NanoDrop 2000c spectrophotometer (Thermo Fisher Scientific, Waltham, MA, USA). Sequences of the primers used for PCR analysis of tPA gene were as follows: for forward and reverse primers: $5^{\prime}$-ATC TTG GGC AGA ACA TAC CG$3^{\prime}$ and $5^{\prime}$-TGC ACT CTT CCC TCT CCT GT-3', respectively. For internal standard using beta actin gene, they were $5^{\prime}$ GAG TCA ACG GAT TTG GTC G-3' and $5^{\prime}$-TCG CTG TTG AAG TCA GAG GA-3' as forward and reverse primers [16]. Total PCR volume was $25 \mu \mathrm{L}$ containing $5 \mu \mathrm{L}$ DNA, Master Mix (Promega) $12.5 \mu \mathrm{L}$, and nuclease free water $1.9 \mu \mathrm{L}$. The cycle was as described by Medcalf et al., 1990 [17]. $5 \mu \mathrm{L}$ of PCR products was analyzed by electrophoresis with $1 \%$ agarose in TAE $1 \mathrm{x}$ buffer and run for 60 minutes $80 \mathrm{~V}$. Quantitative RTPCR was performed using a ChemiDoc ${ }^{\mathrm{TM}}$ (Bio-Rad).

2.5. Animals. Twenty-five male rats (Rattus norvegicus), stock Wistar, weighing 300-400 grams were acclimatized for 7 days in an environmentally controlled room, under protocol number DIS-DLBS-PROC-APC-035. The protocol has been reviewed and approved by the Institutional Animal Care and Use Committee of Dexa Laboratories of Biomolecular Sciences. 
All procedures complied with Standard Operating Procedures and Working Instruction in Animal Pharmacology Laboratories, in accordance with the Guide for the Care and Use of Laboratory Animals [18]; the facilities and programs used have been accredited by AAALAC International. Rats with tail longer than $13 \mathrm{~cm}$ were selected. The tail was ligated with silk 4/0, and the animals were injected with kappa carrageenan, body weight of $1 \mathrm{mg} / \mathrm{kg}$. After 10 minutes, the ligature was removed, and the animals were observed for another 24 hours. The rats were divided into 5 (five) groups: (1) normal control group: injected (i.v.) with aqua as placebo and treated orally with normal saline three times a day, for 8 days; (2) negative control group: injected (i.v.) with kappa carrageenan, body weight of $1 \mathrm{mg} / \mathrm{kg}$, and treated orally with normal saline three times a day for 8 days; (3) positive control group: injected (i.v.) with kappa carrageenan, body weight of $1 \mathrm{mg} / \mathrm{kg}$ (i.v.), and treated orally with lumbrokinase at a dose of $25 \mathrm{mg} / \mathrm{kg}$ body weight, three times a day for 8 days; (4) treatment group with crude enzyme: injected (i.v.) with kappa carrageenan, $1 \mathrm{mg} / \mathrm{kg}$ body weight, and treated orally with crude enzyme at a dose of $25 \mathrm{mg} / \mathrm{kg}$ body weight, three times a day for 8 days; (5) treatment group with semipurified enzyme: injected with kappa carrageenan, body weight of $1 \mathrm{mg} / \mathrm{kg}$, and treated orally with semipurified enzyme at a dose of $25 \mathrm{mg} / \mathrm{kg}$ body weight, three times a day for 8 days. We observed length of the infarcted tail appeared as dark color daily. Quantification of the thrombus follows the following calculation:

$$
\% \text { of thrombus area }=\frac{\text { Length of dark tail on day } 1-\text { length of dark tail on day of observation }}{\text { length of dark tail on day } 1} .
$$

At the end of the study period, the rats were euthanized with sodium pentobarbital, body weight of $150 \mathrm{mg} / \mathrm{kg}$ (i.c.), under anesthesia (ketamine at a dose of $80 \mathrm{mg} / \mathrm{kg}$ and xylazine at a dose of $7.5 \mathrm{mg} / \mathrm{kg}$ body weight i.p.).

2.6. Tail Segment Preparation and Scanning Electron Microscopy. After euthanizing, tails from the experimental rats were removed from the body. The tails were sliced at a width of $0.25 \mathrm{~cm}$ and immersed in fixative solution. The tail segments were rinsed for 10 minutes for sequential dehydration in 50, 75, 85, and 95\% and absolute ethanol. The samples were rinsed twice in acetone for 10 minutes. Dried samples were platinum coated with autofine coater JEOL JFC 1600 and examined at $5 \mathrm{KV}$ in JEOL JSM-6510.

2.7. Statistical Analysis. Data were expressed as mean \pm SEM. Statistical analysis of comparison between normal cells and cells treated with crude and semipurified enzyme was conducted using Student's $t$-test. All animal experimental results were statistically analyzed by one-way ANOVA following post hoc test for multiple comparisons (Tukey's or Games-Howell test) using SPSS ${ }^{\circledR}$ version 23 Statistics software. All statistical tests were at $5 \%$ significance level.

\section{Result}

Previously, the fibrinolytic activities of extracellular enzyme from microorganisms from Indonesian traditional fermented food (Oncom) were screened using fibrin plate and zymogram method [19] and revealed three most potential isolates. These isolates were identified using 16sRNA sequence gene analysis and revealed as Bacillus licheniformis, Bacillus cereus, and Stenotrophomonas sp.

Enzyme from Stenotrophomonas sp. was selected further for PCR analysis and animal experiments due to being the least toxic (shown by MTT assay in Figure 1) and in consideration also of the previous result of the fibrin plate and zymogram analysis. Activities of the crude and ammonium sulphate precipitated (semipurified) enzymes were measured using fibrin degradation assay [14] and the protein concentrations were determined by Lowry's method [15] as shown in Table 1.

3.1. MTT Assay. The MTT analysis was performed as early screening for toxicity, before conducting PCR analysis and experiment on animal models. This assay is useful to test the cell viability and possible cytotoxicity of the enzymes from the three potential fibrinolytic bacteria.

MTT analysis shows different result on 3T3 and HeLa S3 cells counts following treatment of crude enzyme from isolate Stenotrophomonas sp., B. licheniformis, and B. cereus (Figure 1). The 3T3 cell counts show no difference when treated with similar doses of crude enzyme from the three isolates (Figure 1(a)). The results on HeLa S3 cells were however different; the percentages of cell death after treatment with crude enzyme from Stenotrophomonas sp., B. licheniformis, and B. cereus at $40 \mu \mathrm{g} / \mathrm{mL}$ were $24.85 \%, 57.22 \%$ and $77.39 \%$. These percentages were calculated as the initial cell number minus the number of remaining cells (Figure 1(b)) divided by the initial cell number times $100 \%$. Higher percentage means higher cell death. Based on this data, further study was conducted with crude and semipurified enzyme from Stenotrophomonas sp. which appeared as less toxic. Similar effects on HeLa S3 cell count were found when the cells received crude and semipurified enzyme from Stenotrophomonas sp. (Figure 1(c)).

The MTT assay resulted in two important findings: (1) among the three potential fibrinolytic bacteria, enzyme from Stenotrophomonas was found as least toxic and would be used in further experiment; (2) crude and semipurified enzyme from Stenotrophomonas gave similar result and would be also used in further experiments with PCR to find their effect on t-PA expression and used in experimental rats to find their effect on thrombus degradation. The concentrations/doses applied in further experiments took into consideration the 
TABLE 1: Specific activity of fibrinolytic enzyme produced by Stenotrophomonas sp.

\begin{tabular}{lccc}
\hline Sample & Protein $(\mathrm{mg} / \mathrm{mL})$ & Specific activity $(\mathrm{FU})$ & Purification factor $(\mathrm{FU} / \mathrm{mg}$ protein) \\
\hline Crude enzyme & 6.378 & 0.897 & 1.000 \\
Am. sulphate (semipurified enzyme) & 9.321 & 1.340 & 1.024 \\
\hline
\end{tabular}

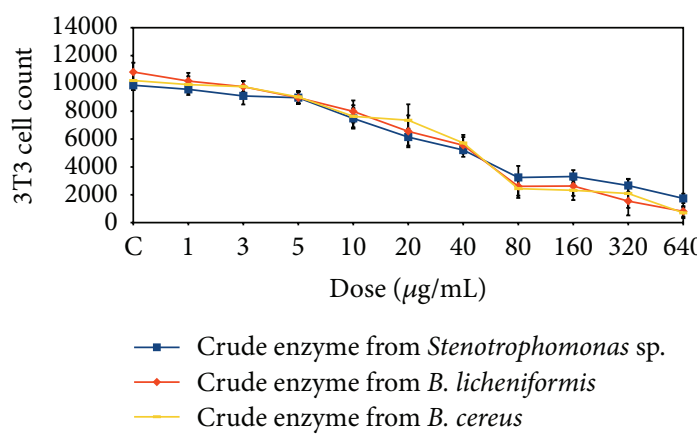

(a)

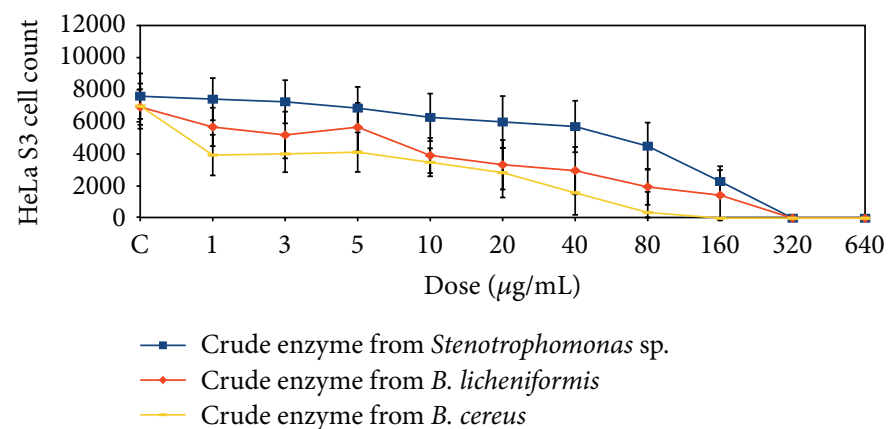

(b)

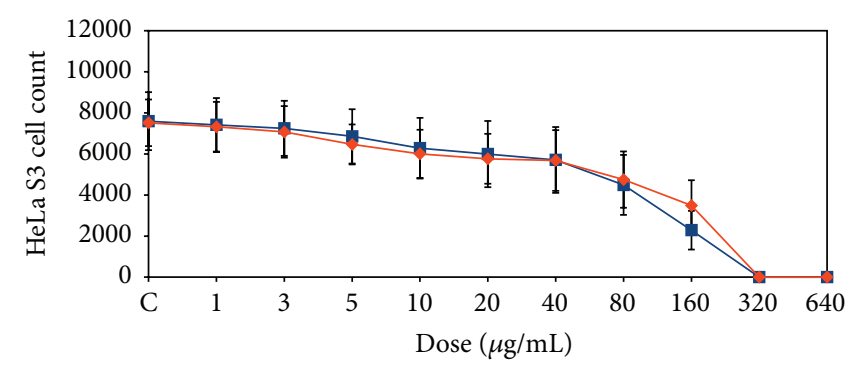

$\rightarrow-$ Crude enzyme from Stenotrophomonas sp.
$\rightarrow-$ Semipurified enzyme from Stenotrophomonas sp.

(c)

FIGURE 1: Cells count after treatments with enzyme from the three isolates. All experiments used MTT assay as mentioned in the method. 3T3 cell counts after treatment with crude enzyme (a); HeLa S3 cell counts after treatment with crude enzyme; (b) HeLa S3 cell counts after treatment with crude and semipurified enzyme from Stenotrophomonas sp. (c).

MTT data and previous study on fibrin plate and zymogram assay.

\subsection{Reverse Transcription Polymerase Chain Reaction Anal-} ysis. PCR method was performed to analyze expression of tissue plasminogen activator (t-PA) gene in HeLa S3 cells following enzyme treatment. The data shows that treatment with crude and semipurified enzyme from Stenotrophomonas sp. increased t-PA expression compared with normal control as shown in Figure 2.

The increased expression of tissue plasminogen activator implies increase in fibrinolysis activity, due to activation of plasminogen into active plasmin.

3.3. Thrombolytic Activity in Experimental Animals. The efficacy of enzyme from Stenotrophomonas sp. to reduce thrombus formation was analyzed using experimental rats. In this study, we applied kappa carrageenan to induce thrombus formation in the rats, because, among different carrageenans, kappa carrageenan was reported as thrombogenic, whereas lambda-carrageenan were inactive in this respect [20]. As the consequence of thrombosis, tail infarction became visible some minutes after intravein administration [21].

Figure 3 shows that injection of kappa carrageenan immediately induced formation of thrombus in the rats tail which appears as dark color. We measured the length of this dark segment in the tail of all experimental groups everyday. Different change of the tail infarction across treatments is shown in Figure 3(a). The percentage of tail infarction was calculated as mentioned in the method. In the negative control group, the percentage started from $100 \%$ after $12 \mathrm{hrs}$ of injection and increased up to $120 \%$ on day 9 . Treatment with crude enzyme, semipurified enzyme (ammonium sulphate precipitated), and lumbrokinase reduced the length of the thrombus formed, which is shown as decrease in percentage of the tail infarction. We found that, in the lumbrokinase group, the dark tail was $70.35 \pm 23.11 \%$ while in the crude enzyme treatment, it reached $56.99 \pm 15.95 \%$ and $71.5 \pm 15.7 \%$ for the treatment with semipurified enzyme. Our observation indicated that the length of the dark tail (implying thrombus) reached $8.9 \pm 3.4 \mathrm{~cm}, 8.4 \pm 4.2 \mathrm{~cm}$, and $10.9 \pm 2.2 \mathrm{~cm}$ after oral treatments with lumbrokinase, crude 


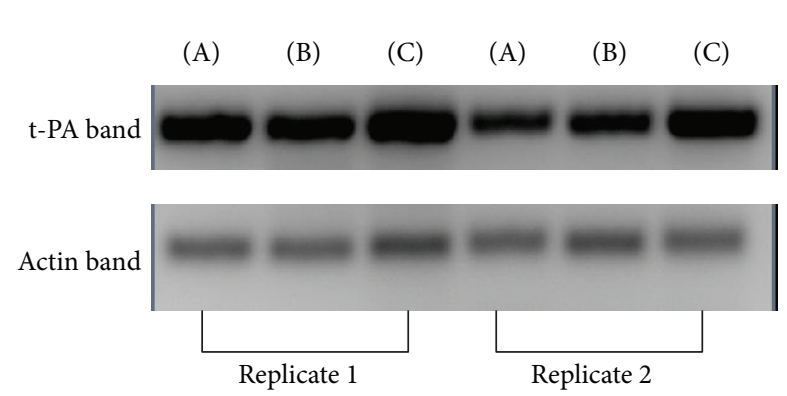

(a)

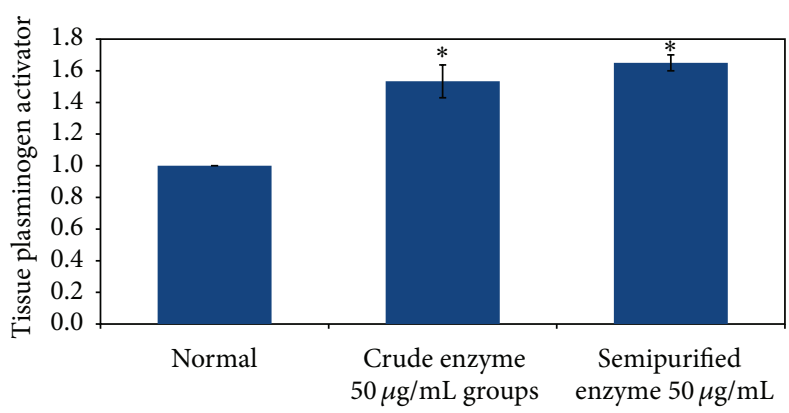

(b)

FIgURE 2: Tissue plasminogen activator expression and quantitative PCR result in HeLa S3 cells. t-PA expression gene in HeLa S3 cells (a); (A) normal control, (B) crude enzyme of Stenotrophomonas sp. $50 \mu \mathrm{g} / \mathrm{mL}$, and (C) semipurified enzyme of Stenotrophomonas sp. $50 \mu \mathrm{g} / \mathrm{mL}$; quantitative PCR (b). * significant difference compared with normal $(p<0.05)$.
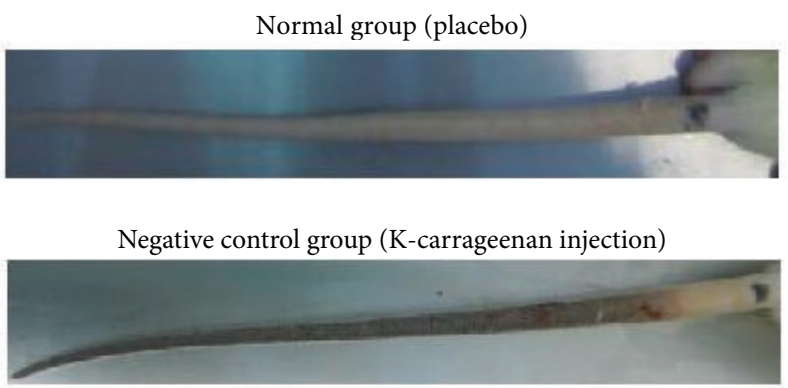

Crude enzyme of Stenotrophomonas sp. $25 \mathrm{mg} / \mathrm{kg}$ BW
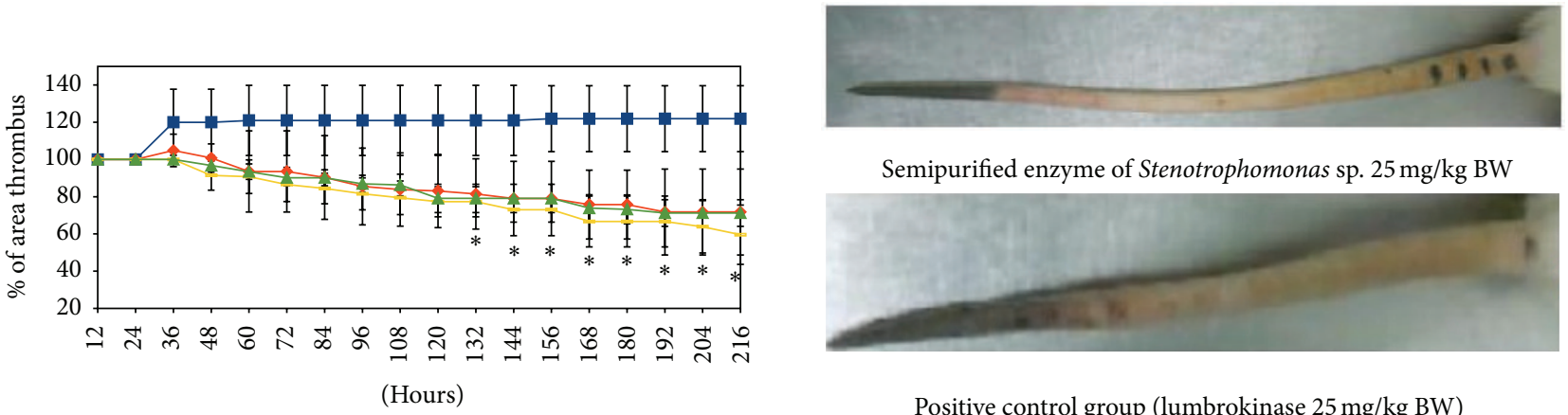

Semipurified enzyme of Stenotrophomonas sp. $25 \mathrm{mg} / \mathrm{kg} \mathrm{BW}$

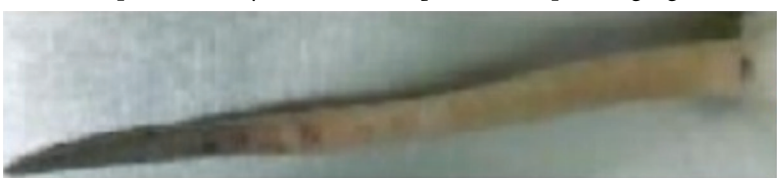

$\rightarrow$ Negative control group (K-carrageenan injection)
$\rightarrow$ Positive control group (lumbrokinase $25 \mathrm{mg} / \mathrm{kg} \mathrm{BW}$ )
$\rightarrow$ Crude enzyme of Stenotrophomonas sp. $25 \mathrm{mg} / \mathrm{kg} \mathrm{BW}$
$\rightarrow$ Semipurified enzyme of Stenotrophomonas sp. $25 \mathrm{mg} / \mathrm{kg} \mathrm{BW}$

(a)
Positive control group (lumbrokinase $25 \mathrm{mg} / \mathrm{kg} \mathrm{BW}$ )

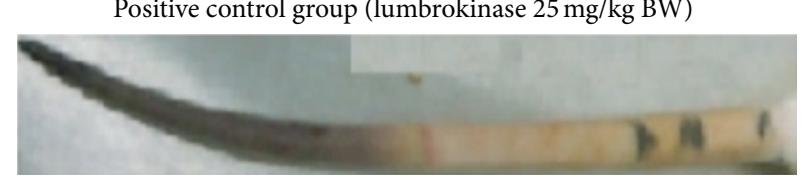

(b)

FIgURE 3: Thrombus degradation in rats tail following oral enzyme treatment. Percentage of thrombus left (a). Thrombus area on day fifth (b). ${ }^{*}$ significance difference compared with negative control group $(p<0.05)$.

enzyme (Stenotrophomonas sp.), and semipurified enzyme, respectively, while the dark tail segment in the negative control remained $13 \mathrm{~cm}$.

Thrombus formed in the rat tail induced by carrageenan injection was much reduced by oral treatments of crude enzyme, semipurified enzyme of Stenotrophomonas sp., and also lumbrokinase (in the positive control group). At the end of the treatments period, there was sign of gangrene in the rat tail, especially in the negative control. Gangrene is a term used to describe decay or death of an organ or tissue, due to lack of blood supply. This condition was influenced by the presence of clot formation due to kappa carrageenan injection.

Analysis using scanning electron microscopy was conducted at 250x magnification and focused on the tail vein, in order to visualize formation of the thrombus. Figure 4 shows experimental results for four different treatments. The result confirms that $\mathrm{K}$-carrageenan injection produced blood clots or thrombus (Figure 4(b)) while the normal control group did not reveal any blockages in the blood vessels (Figure 4(a)). There were significant differences found in 

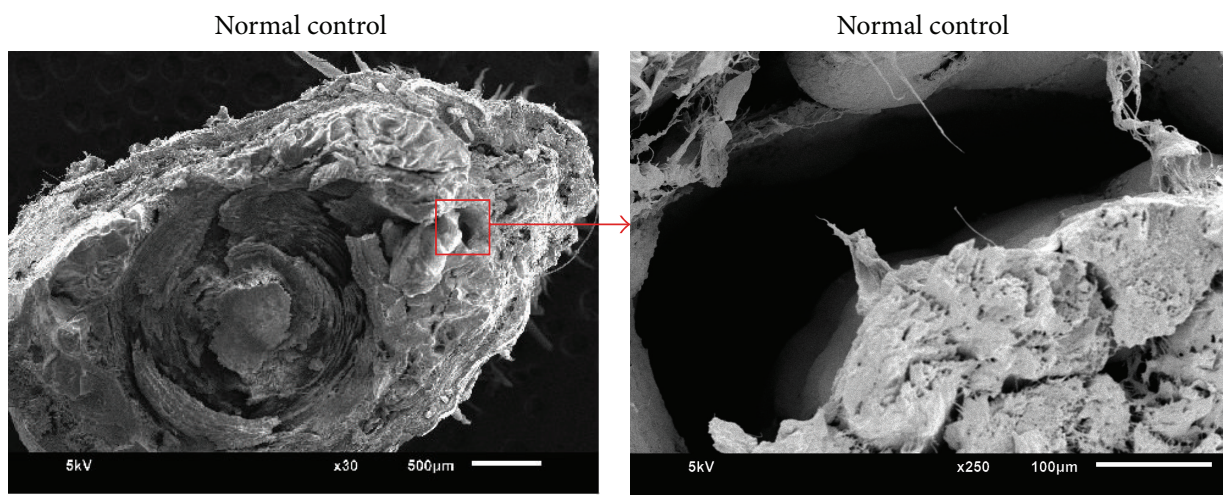

(a)
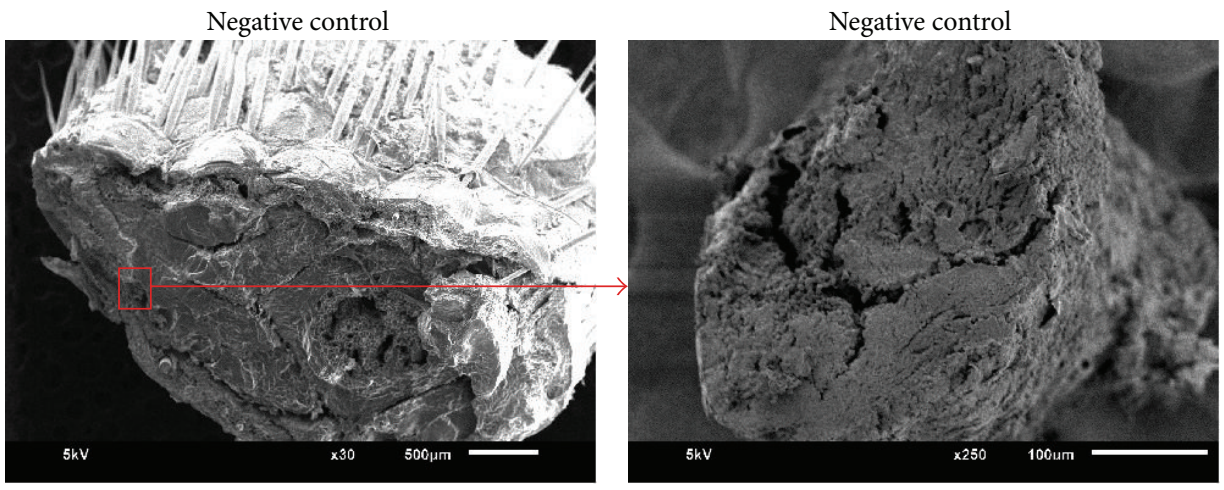

(b)
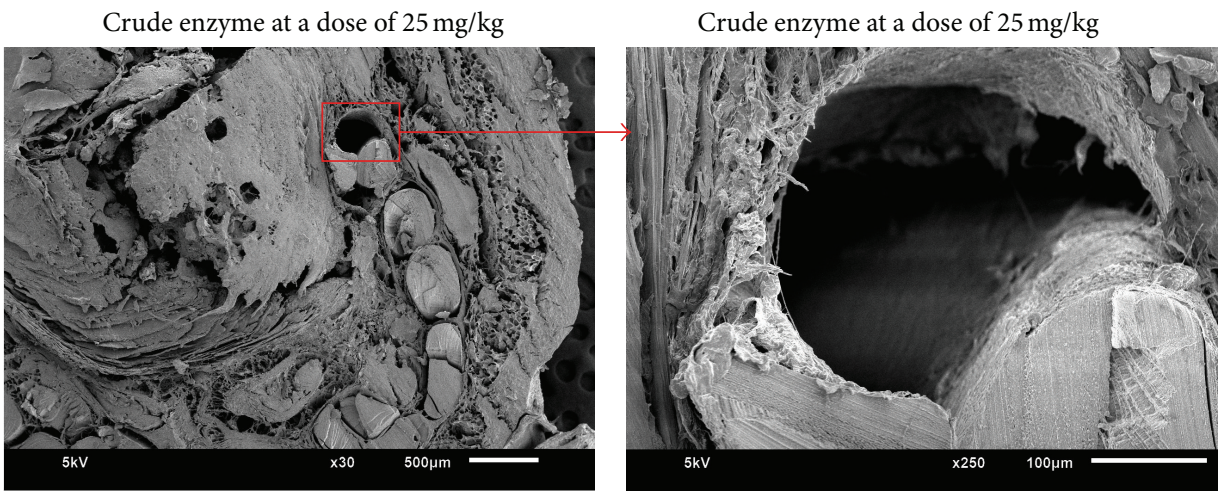

(c)
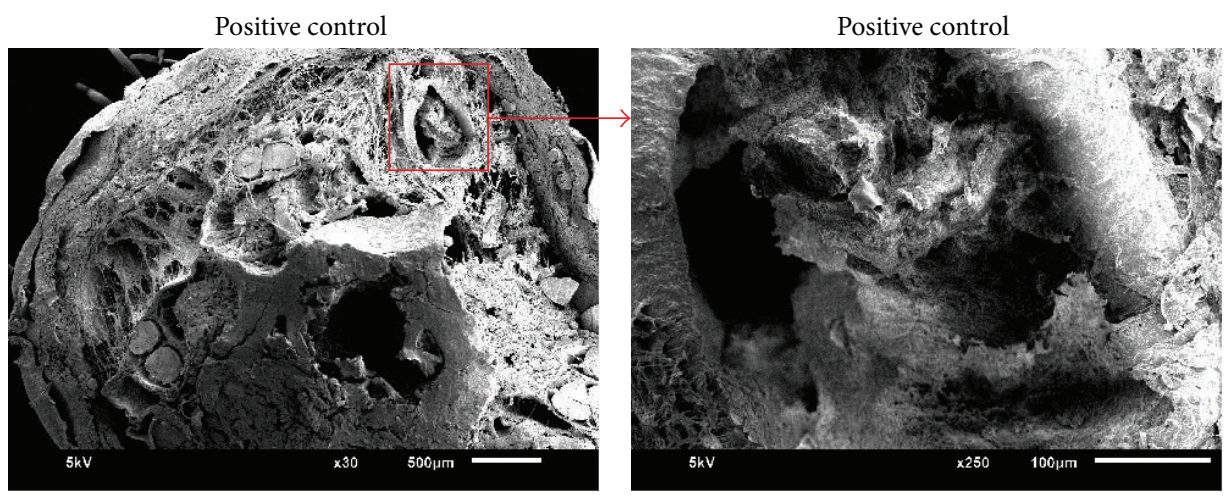

(d)

FIgURE 4: Scanning electron microscopy of the tail cross section from the experimental rats (including blood vessels). Normal control (a); negative control (kappa carrageenan injection) (b); crude enzyme of Stenotrophomonas sp. $25 \mathrm{mg} / \mathrm{kg}$ BW (c); positive control (lumbrokinase $25 \mathrm{mg} / \mathrm{kg} \mathrm{BW})(\mathrm{d})$. 
TABLE 2: Blood parameter.

\begin{tabular}{lccccc}
\hline Blood parameters & $\begin{array}{c}\text { Normal control } \\
\text { group }\end{array}$ & $\begin{array}{c}\text { Negative control } \\
\text { group }\end{array}$ & $\begin{array}{c}\text { Group } \\
\text { Positive control } \\
\text { group }\end{array}$ & $\begin{array}{c}\text { Crude enzyme of } \\
\text { Stenotrophomonas sp. }\end{array}$ & $\begin{array}{c}\text { Semipurified enzyme of } \\
\text { Stenotrophomonas sp. }\end{array}$ \\
\hline RBC & $6.72 \pm 0.28$ & $6.77 \pm 0.35$ & $6.59 \pm 0.22$ & $6.79 \pm 0.32$ & $7.44 \pm 0.45^{\mathrm{a}}$ \\
WBC & $4.21 \pm 0.49$ & $5.21 \pm 2.08$ & $6.07 \pm 1.71$ & $7.34 \pm 1.36$ & $8.18 \pm 2.41^{\mathrm{a}}$ \\
PLT & $708.10 \pm 35.8$ & $942.00 \pm 97.89^{\mathrm{a}}$ & $913.60 \pm 97.64^{\mathrm{a}}$ & $875.10 \pm 79.66^{\mathrm{a}}$ & $851.90 \pm 70.65$ \\
HGB & $13.67 \pm 0.41$ & $13.21 \pm 0.90$ & $13.75 \pm 0.56$ & $12.38 \pm 0.66$ & $14.84 \pm 0.51$ \\
HCT & $36.60 \pm 1.00$ & $35.92 \pm 2.23^{\mathrm{e}}$ & $36.38 \pm 1.11^{\mathrm{e}}$ & $36.71 \pm 1.93$ & $39.54 \pm 1.35^{\mathrm{bc}}$ \\
MCV & $54.53 \pm 1.11$ & $53.03 \pm 1.03$ & $55.21 \pm 1.65$ & $54.03 \pm 0.70$ & $53.19 \pm 1.37$ \\
MCH & $20.36 \pm 0.35$ & $19.51 \pm 0.51^{\mathrm{cd}}$ & $20.87 \pm 0.71^{\mathrm{b}}$ & $20.59 \pm 0.41^{\mathrm{b}}$ & $19.96 \pm 0.56$ \\
MCHC & $37.35 \pm 0.20^{\mathrm{d}}$ & $36.75 \pm 0.29^{\mathrm{cde}}$ & $37.80 \pm 0.49^{\mathrm{b}}$ & $38.13 \pm 0.43^{\mathrm{ab}}$ & $37.54 \pm 0.38^{\mathrm{b}}$ \\
\hline $\mathrm{a} p<0.05$ in experimental group compared with & & & &
\end{tabular}

${ }^{\mathrm{a}} p<0.05$ in experimental group compared with normal group.

${ }^{\mathrm{b}} p<0.05$ in experimental group compared with negative control group.

${ }^{c} p<0.05$ in experimental group compared with treatment group and positive control group (lumbrokinase).

${ }^{\mathrm{d}} p<0.05$ in experimental group compared with treatment group, crude enzyme of Stenotrophomonas sp.

${ }^{\mathrm{e}} p<0.05$ in experimental group compared with treatment group, semipurified enzyme of Stenotrophomonas sp.

RBC: red blood cell, WBC: white blood cell, PLT: platelet count, HGB: hemoglobin, HCT: hematocrit, MCV: mean corpuscular volume, MCH: mean corpuscular hemoglobin, and MCHC: mean corpuscular hemoglobin concentration.

the negative control and the treatment groups. The veins in negative control group were covered by thrombus, while, for treatment groups, a significant part was becoming clear indicating less or no blockage (Figures $4(\mathrm{c})$ and $4(\mathrm{~d})$ ).

3.4. Hematology. To measure the health status of the experimental rats following enzyme treatment, we performed blood analysis at the end of the experiment. The hematology data were within the normal values for Rattus norvegicus [22], which implies that treatments with crude and semipurified enzyme of Stenotrophomonas sp. did not alter the health status (Table 2). Kappa carrageenan injection influenced the platelet count statistically. Platelet or thrombocytes are involved in hemostasis, leading to formation of blood clots which was already observed in Figure 3 (dark color tail infarction). Compared with the rats in the negative control, we observed slight decrease in platelet count in all treatment groups. Within the group of semipurified enzyme, the platelet values were lower as expected and not significantly different from those of the normal group $(p>0.05)$.

\section{Discussion}

Thrombotic complications of cardiovascular disease are the main causes of death and disability in many patients. Thrombolysis have been used to lower the burden of such lifethreatening diseases as myocardial infarction, cerebrovascular thrombosis, and venous thromboembolism. The primary approach in the treatment is both prevention and removal of blood clot. The most effective way to remove blood clot is through the use of thrombin inhibitor or plasminogen activator, which prevent formation of the blood clot or degrade the blood clot, respectively. Indeed, most of drugs developed for CVD treatment are based on either of those approaches. Use of enzymes of therapeutic relevance in treating diseases is increasingly popular, in particular for cardiovascular disease.
Thrombolytic agents (enzyme/protein) are classified into two types based on the working mechanisms. Tissue plasminogen activators such as t-PA and urokinase degrade fibrin through activation of plasminogen into active plasmin which in turn will solubilize fibrin in the blood clot and plasmin-like proteins which directly degrade fibrin [8-10].

Several studies have indicated that microorganisms can produce thrombolytic enzyme, which could reduce thrombus formation or act as tissue plasminogen activator and plasminlike protein $[19,23]$. Recently, microbial fibrinolytic enzymes of food origin receive a lot of attention. This situation opens opportunity to explore traditional fermented foods that have been used to treat diseases related to thrombosis. Numerous potent fibrinolytic microorganisms have been isolated from traditional fermented food, such as Korean Chung Gook-Jang, Japanese natto, Chinese Douchi, and Indonesian Tempe [2, 1114].

We have successfully isolated fibrinolytic microorganisms from local (Indonesian) fermented soy bean Oncom. Among the microorganisms, a potent isolate was identified as Stenotrophomonas sp. which is unique, because most of food origin fibrinolytic microorganism reported belongs to Bacillus sp. The extracellular enzymes can degrade fibrinogen in the serum component completely, suggesting the potential application in the process of blood clot solubilization (unpublished data). The fibrinolytic activity was similar to that demonstrated by lumbrokinase (LK) from earthworms Lumbricus rubellus which is known for high fibrinolytic activity $[10,19,23]$. The finding of this bacteria upon screening of microbes with fibrinolytic activity is surprising, since genus Stenotrophomonas is not yet well explored, but has been associated with variety of beneficial functions and applications, such as plant growth.

Qualified and affordable thrombolysis drugs are urgently needed to reduce the incidence of CVD without neglecting the safety and efficacy of new drugs candidates. The safety 
studies are usually initiated by using cell culture experiment before proceeding to experimental animals, to avoid conditions that might be harmful to the animal models. In this experiment, enzymes from the three isolates were tested using HeLa S3 and 3T3 cells. The enzyme from isolate Stenotrophomonas sp. appeared as somewhat least toxic compared to other enzymes. Therefore, we used this enzyme for further animal experiment.

In this study, we observed higher t-PA expression in HeLa S3 cells, when incubated with fibrinolytic enzyme from Stenotrophomonas sp. The expression of t-PA gene can be regulated by both transcriptional and translational mechanisms [4]. Several studies have indicated that t-PA promoter in HeLa cells identified two keys of regulatory region: the first one is related to cAMP responsive element (CRE), and the other is related to sequence similarity to AP2. The expression of t-PA is also regulated by a variety of effectors including cytokines tumor necrosis factor, interleukin, epidermal growth factor, and retinoid tumor promoters [4, 24]. Inflammation can induce plasminogen activator inhibitor-1 (PAI-1) expression that will rapidly induce thrombosis, by activating the coagulation pathway [25].

Carrageenans are family of linear sulphated polysaccharides extracted from red seaweeds [23]. Carrageenan can be used to establish a mouse thrombolytic model involving blackening of the tail due to local inflammation and cell damage to necrosis $[13,26-28]$ and induced colonic inflammation with development of inflammatory infiltrates, ulceration, and colitis [29]. Necrosis of the tail is associated with vascular thrombosis [20] when carrageenan is administered systemically, due to its agglutinating activity against blood cells [30]. Infarcted tails of rats after carrageenan injection for induction of thrombosis were also shown in previous study to evaluate the fibrinolytic activity of nattokinase [31]. In our study, inflammation and blackening tail were found soon after carrageenan injection. These symptoms were much reduced by oral treatment of the fibrinolytic enzymes from Stenotrophomonas sp. and lumbrokinase. Similar result was observed by oral treatment of nattokinase, a fibrinolytic enzyme from Bacillus natto isolated from the Japanese traditional fermented food Natto [2, 11]. Apparently, oral treatment of fibrinolytic enzyme for a suitable period of time could be effective in reducing thrombus in the animal organ. The ability to maintain fibrinolytic activity at the animal stomach was observed with another fibrin degrading enzyme, namely, lumbrokinase from the earthworm $[10,19,32]$. The enzyme appeared to be effectively absorbed across the rat intestinal tract [32]. Electron microscopic analysis in our study confirmed the ability of Stenotrophomonas enzyme given orally to reach and actively reduce thrombus formed in the rats tail. Safety of the experimental animals following enzyme treatment in our study is reflected by the normal blood parameters observed at the end of experiment.

\section{Conclusion}

In conclusion, we confirmed the safety of enzyme (applied as crude or semipurified form) from Stenotrophomonas sp. isolated from Indonesian fermented food Oncom in cell culture and experimental rats. The effects of crude and semipurified enzyme on thrombus degrading activity were also similar. The potent thrombolytic activity of the enzymes was shown as significant reduction of kappa carrageenan induced thrombus formation in our experimental rat and also shown through scanning electron microscopy examination.

\section{Competing Interests}

The authors declared no conflict of interests with respect to the authorship and/or publication.

\section{Acknowledgments}

The authors thanks Diana Nur Afifah for preparation the Oncom isolates under supervision of Maggy T. Suhartono, Laurentia Stephani for performing fibrinolysis examination, and Frans Kurnia for bacterial identification. This research was supported by research grant for biotech graduate students of Atma Jaya University and Dexa Laboratories of Biomolecular Sciences (DLBS), Dexa Medica, Indonesia.

\section{References}

[1] Global Health Observatory, "Cardiovascular diseaase mortality: age-standardized death rate per 100000 population, 2000-2012," World Health Organization, http://gamapserver.who.int/gho/ interactive_charts/ncd/mortality/cvd/atlas.html.

[2] Y. Peng, X. Yang, and Y. Zhang, "Microbial fibrinolytic enzymes: an overview of source, production, properties, and thrombolytic activity in vivo," Applied Microbiology and Biotechnology, vol. 69, no. 2, pp. 126-132, 2005.

[3] H. Morishita, N. Nakamura, T. Yamakawa et al., "Stable expression of human tissue-type plasminogen activator regulated by $\beta$-actin promoter in three human cell lines: HeLa, WI-38 VA13 and KMS-5," Biochimica et Biophysica Acta (BBA)-Gene Structure and Expression, vol. 1090, no. 2, pp. 216-222, 1991.

[4] J. W. Kim, S. H. Lee, H. M. Ko et al., "Biphasic regulation of tissue plasminogen activator activity in ischemic rat brain and in cultured neural cells: essential role of astrocyte-derived plasminogen activator inhibitor-1," Neurochemistry International, vol. 58, no. 3, pp. 423-433, 2011.

[5] M. Loren, L. J. Garcia Frade, M. C. Torrado, and J. L. Navarro, "Thrombus age and tissue plasminogen activator mediated thrombolysis in rats," Thrombosis Research, vol. 56, no. 1, pp. 6775, 1989.

[6] S. Absar, Y. M. Kwon, and F. Ahsan, "Bio-responsive delivery of tissue plasminogen activator for localized thrombolysis," Journal of Controlled Release, vol. 177, no. 1, pp. 42-50, 2014.

[7] K. Yamada, H. Tsuji, S. Kimura et al., "Effects of argatroban and heparin on thrombus formation and tissue plasminogen activator-induced thrombolysis in a microvascular thrombosis model," Thrombosis Research, vol. 109, no. 1, pp. 55-64, 2003.

[8] D. Collen and H. R. Lijnen, "Tissue-type plasminogen activator: a historical perspective and personal account," Journal of Thrombosis and Haemostasis, vol. 2, no. 4, pp. 541-546, 2004.

[9] H. M. Chen, A. L. Guan, and F. S. Markland Jr., "Immunological properties of the fibrinolytic enzyme (fibrolase) from southern copperhead (Agkistrodon contortrix contortrix) venom and its 
purification by immunoaffinity chromatography," Toxicon, vol. 29, no. 6, pp. 683-694, 1991.

[10] H. Mihara, H. Sumi, T. Yoneta et al., "A novel fibrinolytic enzyme extracted from the earthworm, Lumbricus rubellus," Japanese Journal of Physiology, vol. 41, no. 3, pp. 461-472, 1991.

[11] C. Yongjun, B. Wei, J. Shujun et al., "Directed evolution improves the fibrinolytic activity of nattokinase from Bacillus natto," FEMS Microbiology Letters, vol. 325, no. 2, pp. 155-161, 2011.

[12] Y. Peng and Y. Z. Zhang, "Optimation of fermentation conditions of douchi fibrinolytic enzyme produced by Bacillus amyloliquefaciens DC-4," Chinese Journal of Applied \& Environmental Biology, vol. 8, pp. 285-289, 2002.

[13] J. Yuan, J. Yang, Z. Zhuang, Y. Yang, L. Lin, and S. Wang, "Thrombolytic effects of douchi fibrinolytic enzyme from Bacillus subtilis LD-8547 in vitro and in vivo," BMC Biotechnology, vol. 12, article 36, 2012.

[14] Y. Hua, B. Jiang, Y. Mine, and W. Mu, "Purification and characterization of a novel fibrinolytic enzyme from Bacillus sp. nov. SK006 isolated from an Asian traditional fermented shrimp paste," Journal of Agricultural and Food Chemistry, vol. 56, no. 4, pp. 1451-1457, 2008.

[15] O. H. Lowry, N. J. Rosebrough, A. L. Farr, and R. J. Randall, "Protein measurement with the folin phenol reagent," The Journal of Biological Chemistry, vol. 193, no. 1, pp. 265-275, 1951.

[16] C. Yatagai, M. Maruyama, T. Kawahara, and H. Sumi, "Nattokinase-promoted tissue plasminogen activator release from human cells," Pathophysiology of Haemostasis and Thrombosis, vol. 36, no. 5, pp. 227-232, 2007-2008.

[17] R. L. Medcalf, M. Rüegg, and W.-D. Schleuning, "A DNA motif related to the cAMP-responsive element and an exonlocated activator protein-2 binding site in the human tissuetype plasminogen activator gene promoter cooperate in basal expression and convey activation by phorbol ester and cAMP," Journal of Biological Chemistry, vol. 265, no. 24, pp. 14618-14626, 1990.

[18] NRC, Guide for the Care and Use of Laboratory Animals, National Research Council, Washington, DC, USA, 8th edition, 2011.

[19] J. Trisina, F. Sunardi, M. T. Suhartono, and R. R. Tjandrawinata, "DLBS1033, a protein extract from Lumbricus rubellus, possesses antithrombotic and thrombolytic activities," Journal of Biomedicine and Biotechnology, vol. 2011, Article ID 519652, 7 pages, 2011.

[20] R. Kod’ousek, J. Jezdínský, and D. Krajčí, "Histological and ultrastructural changes of cardiomyocytes in experimental rats with tail thrombosis following subplantar application of carrageenin," Medical Principles and Practice, vol. 16, no. 5, pp. 360-366, 2007.

[21] H. Bekemeier, R. Hirschelmann, and A. J. Giessler, "Carrageenin-induced thrombosis in the rat and mouse as a test model of substances influencing thrombosis," Biomedica Biochimica Acta, vol. 43, no. 8-9, pp. S347-S350, 1984.

[22] E. V. Hillyer and K. E. Quensberry, Ferrets, Rabbits and Rats Clinical Medicine and Surgery, WB Saunders, Philadelphia, Pa, USA, 1997.

[23] M. Jin, W. Chen, W. Huang, L. Rong, and Z. Gao, "Preparation of pegylated lumbrokinase and an evaluation of its thrombolytic activity both in vitro and in vivo," Acta Pharmaceutica Sinica B, vol. 3, no. 2, pp. 123-129, 2013.

[24] M. Costa and R. L. Medcalf, "Differential binding of cAMPresponsive-element(CRE)-binding protein-1 and activating transcription factor-2 to a CRE-like element in the human tissue-type plasminogen activator ( $\mathrm{t}-\mathrm{PA}$ ) gene promoter correlates with opposite regulation of t-PA by phorbol ester in HT-1080 and HeLa cells," European Journal of Biochemistry, vol. 237, no. 3, pp. 532-538, 1996.

[25] K. A. Stringer, S. K. Bose, and J. M. McCord, "Antiinflammatory activity of tissue plasminogen activator in the carrageenan rat footpad model," Free Radical Biology and Medicine, vol. 22, no. 6, pp. 985-988, 1997.

[26] S. J. Hu, Q. L. Tian, and J. W. Gu, "A new in vivo animal model of thrombosis formation," Journal of The Fourth Military Medical University, vol. 14, article 69, 1993.

[27] S. Majumdar, S. Dutta, T. Das, P. Chattopadhyay, and A. K. Mukherjee, "Antiplatelet and antithrombotic activity of a fibrin(ogen)olytic protease from Bacillus cereus strain FF01," International Journal of Biological Macromolecules, vol. 79, pp. 477-489, 2015.

[28] R. Arslan, Z. Bor, N. Bektas, A. H. Meriçli, and Y. Ozturk, "Antithrombotic effects of ethanol extract of Crataegus orientalis in the carrageenan-induced mice tail thrombosis model," Thrombosis Research, vol. 127, no. 3, pp. 210-213, 2011.

[29] S. Bhattacharyya, L. Xue, S. Devkota, E. Chang, S. Morris, and J. K. Tobacman, "Carrageenan-induced colonic inflammation is reduced in Bcl10 null mice and increased in IL-10-deficient mice," Mediators of Inflammation, vol. 2013, Article ID 397642, 13 pages, 2013.

[30] M. M. Burger, "Cell surface alterations in transformed and mitotic normal cells monitored with plant agglutinins," Neoplasma, vol. 20, no. 5, pp. 579-581, 1973.

[31] S. Kamiya, M. Hagimori, M. Ogasawara, and M. Arakawa, "In vivo evaluation method of the effect of nattokinase on carrageenan-induced tail thrombosis in rat model," Acta Haematologica, vol. 124, pp. 218-224, 2010.

[32] R. R. Tjandrawinata, J. Trisina, P. Rahayu, L. A. Prasetya, A. Hanafiah, and H. Rachmawati, "Bioactive protein fraction DLBS1033 containing lumbrokinase isolated from Lumbricus rubellus: ex vivo, in vivo, and pharmaceutic studies," Drug Design, Development and Therapy, vol. 8, pp. 1585-1593, 2014. 

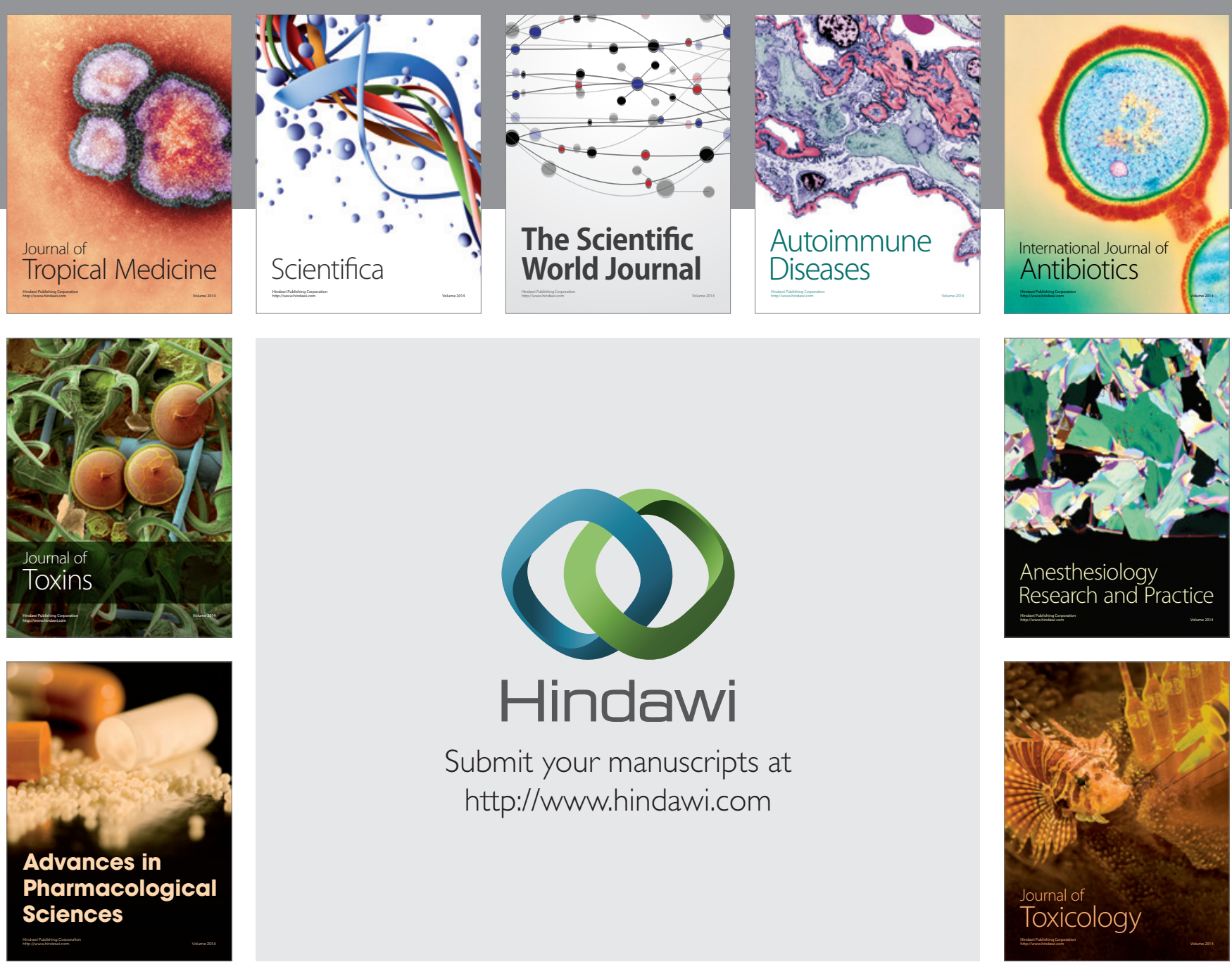

\section{Hindawi}

Submit your manuscripts at

http://www.hindawi.com
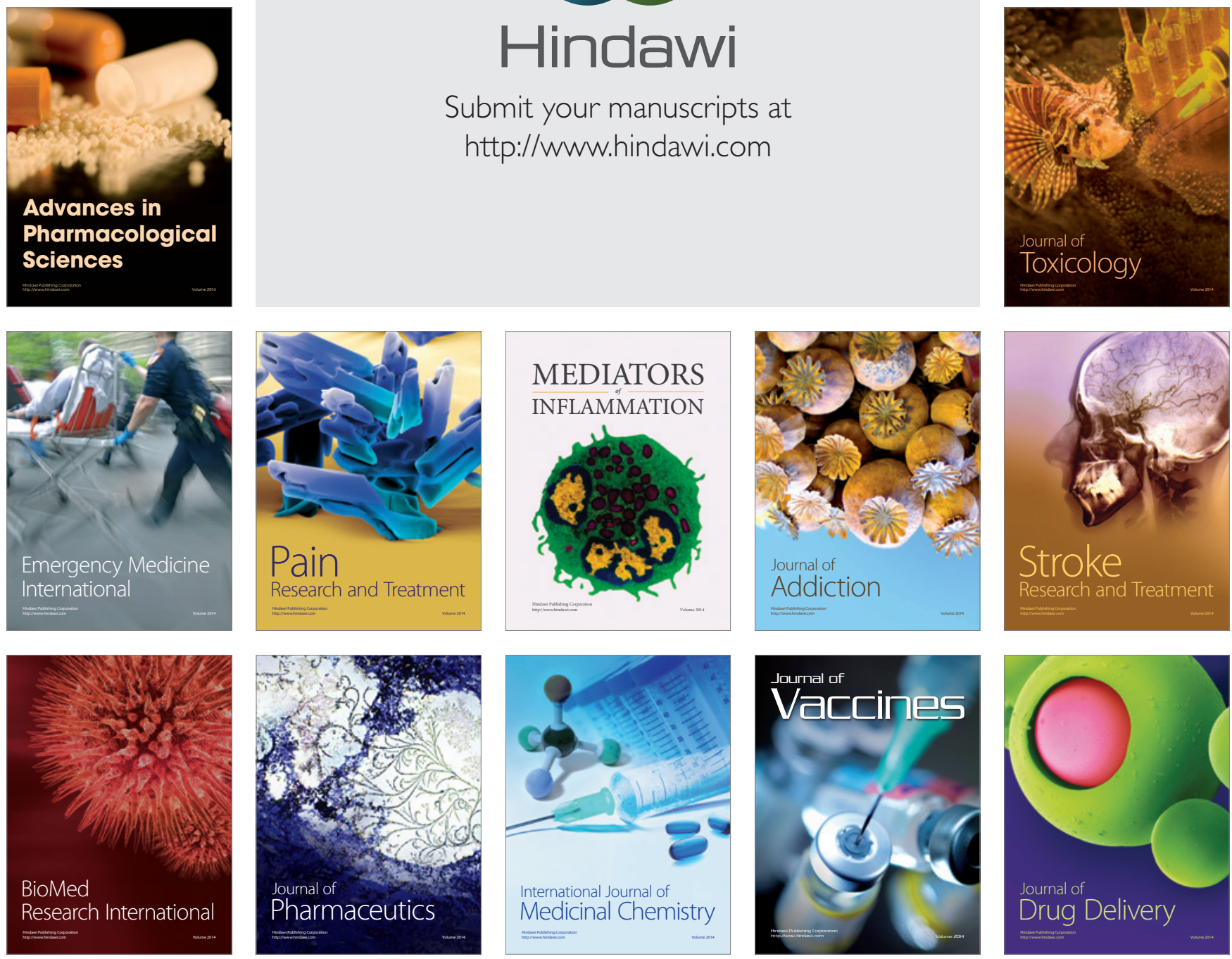